\title{
REACTIVITY AND POLYMERIZATION ABILITY OF STYRYLQUINOLINE CONTAINING METHACRYLIC MONOMERS
}

\author{
Oksana Kharchenko ${ }^{1, *}{ }^{,}$, Vitaliy Smokal ${ }^{1}, 0$ ksana Krupka ${ }^{1}$, Aleksey Kolendo ${ }^{1}$
}

https://doi.org/10.23939/chcht12.01.047

\begin{abstract}
Novel styrylquinoline methacrylic monomers and their copolymers with methylmethacrylate (MMA) are presented. The polymerization was carried out in DMF with AIBN as initiator. The products of polymerization were characterized by ${ }^{1} \mathrm{H}$ NMR. The monomer reactivity ratios for the homogeneous free-radical copolymerization of styrylquinoline monomers and MMA were determined from ${ }^{1}$ H NMR spectroscopy data and estimated with the Fineman-Ross (FR) and calculation methods.
\end{abstract}

Keywords: 8-methacryloyloxy styrylquinoline, FinemanRoss method, monomer reactivity ratio, free radical polymerization.

\section{Introduction}

In the recent years, the development of modern technologies enables one to create polymer materials with a number of properties which would be impossible to realize in a single polymer. The side chain methacrylic polymers with different active functional group have been well studied and widely applied in many fields, such as: optoelectronics, nonlinear optics, optical storage materials, biochemicals and medicine. Thus, creation of these polymers is one of topical problems of modern polymer chemistry. Photopolymers are studied for their macromolecular properties and for the properties of the photosensitive group. Among them, polymers having photochromic dyes, such as azo, cinnamoyls, chalcones, coumarins, spyrooxazines, diarylethenes, etc., represent an active field of research in polymer science because of their technological applications in the fields of photolithography, nonlinear optical materials, liquid crystalline materials, and holographic elements [1-5].

The styryl dyes with quinoline nucleus were applied to various sensitive materials such as sensitizers or desensitizers formerly. With the development of new technologies, the researchers have found a new application of styrylquinoline dyes to electroluminescence

\footnotetext{
${ }^{1}$ Kyiv Taras Shevchenko National University,

60, Volodymyrska St., 01033 Kyiv, Ukraine

*oksana_kharchenko@ukr.net

(c) Kharchenko O., Smokal V., Krupka O., Kolendo A., 2018
}

[6] and photochromism [7, 8] as well as in the field of medication [9-13].

The copolymer composition and comonomers units distribution depend on monomer reactivity ratios. The most common mathematical model of copolymerization is based on finding the relationship between the composition of copolymers and the composition of the monomer feed, in which the monomer-reactivity ratios are the parameters to be determined [14]. The calculation of the monomerreactivity ratios requires the mathematical treatment of experimental data on the composition of copolymers and monomer in feed mixtures. The most fundamental value characterizing a copolymer is its composition on a molar basis, which is eventually used for the determination of the relevant monomer reactivity ratios. Spectroscopic methods, preferably ${ }^{1} \mathrm{H}$ NMR spectroscopy, and elemental analysis are probably the most widely used methods for the analysis of copolymers and the determination of reactivity ratios.

The objective of this work is to investigate the polymerization ability and reactivity ratios of 8 methacryloxy styrylquinoline. This paper describes synthesis of polymers by free radical homo- and copolymerization of 8-methacryloxy styrylquinoline with MMA initiated by AIBN.

\section{Experimental}

\subsection{M aterials}

MMA, ethanol, methanol, $N, N$-dimethylformamide (DMF), tetrahydrofuran (THF), were distilled before use [15], methacryloyl chloride, azobisisobutyronitrile (AIBN) and 2-methylquinolin-8-ol were used without further purification.

\subsection{M easurements}

${ }^{1} \mathrm{H}$ NMR spectra were obtained on a "Mercury" $400 \mathrm{MHz}$ Bruker, using $\mathrm{CDCl}_{3}, \mathrm{DMSO}-\mathrm{d}_{6}$ as the solvents and tetramethylsilane as an internal standard. Infrared spectra were recorded on Perkin Elmer BX with $\mathrm{KBr}$. 


\subsection{Synthesis of 2-Styrylquinoline-8-ol Derivatives}

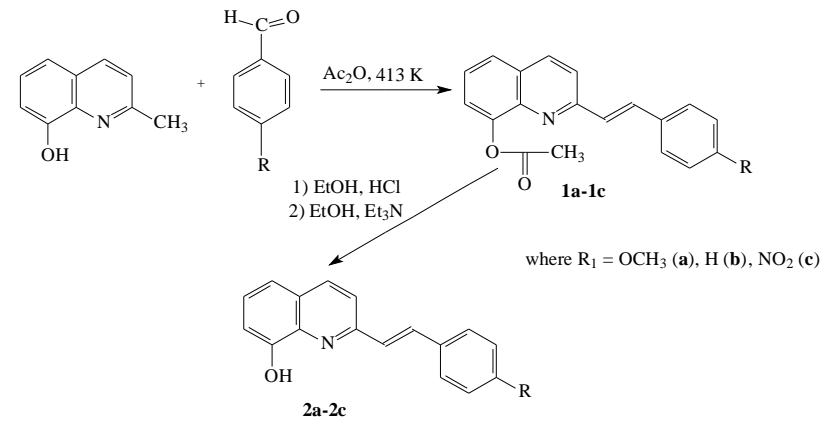

Scheme 1. Synthesis of 2-styrylquinoline-8-ol derivatives

2-[2-(4-methoxythenyl]quinolin-8-yl acetate (1a). A flask was charged with a mixture of 8-hydroxy-2methylquinoline $(3.02 \mathrm{~g}, 18.99 \mathrm{mmol}), \quad$ 4-methoxybenzaldehyde $(5.2 \mathrm{~g}, 38.29 \mathrm{mmol})$ and acetic anhydride $(20 \mathrm{ml})$. It was refluxed and heated at $413 \mathrm{~K}$ for $14 \mathrm{~h}$ (TCL monitoring). To the cooled reaction mixture icecold water was added. The precipitated product, which appeared upon dilution with ice/water mixture, was filtered off, washed several times with water, dried and crystallized from ethanol, yield 58\%. Mp 397-398 K. ${ }^{1} \mathrm{H}$ NMR $\left(400 \mathrm{~Hz}\right.$, DMSO-d $\left.\mathrm{d}_{6}\right), \delta$, ppm: $2.53 \quad(\mathrm{~s}, 3 \mathrm{H}$, $\left.-\mathrm{CH}_{3}\right), 3.81$ (s, 3H, $\left.-\mathrm{OCH}_{3}\right), 6.85(\mathrm{~d}, 2 \mathrm{H}, \mathrm{Ar}-\mathrm{H}), 7.52(\mathrm{~m}$, $2 \mathrm{H}, \mathrm{Ar}-\mathrm{H}), 7.15(\mathrm{~d}, 1 \mathrm{H},-\mathrm{CH}=), 7.56(\mathrm{~m}, 1 \mathrm{H},-\mathrm{CH}=), 7.15$ (d, 1H, Het), 7.38 (t, 1H, Het), 7.47 (m, 1H, Het), 7.54 (m, $1 \mathrm{H}, \mathrm{Het}), 7.96$ (d, 1H, Het).

2-(2-phenylethenyl)quinolin-8-yl acetate (1b) The same procedure as for $1 \mathbf{a}$ was used for benzaldehyde. The solid residue was recrystallized from ethanol to give $\mathbf{1 b}$ yield $76 \%$. Mp 386-387 K. ${ }^{1} \mathrm{H}$ NMR $(400 \mathrm{~Hz}$, DMSO$\left.\mathrm{d}_{6}\right), \delta$, ppm: $2.51\left(\mathrm{~s}, 3 \mathrm{H},-\mathrm{CH}_{3}\right), 7.32(\mathrm{~m}, 1 \mathrm{H}, \mathrm{Het}), 7.36$ (m, 1H, Het), $7.40(\mathrm{~m}, 2 \mathrm{H}, \mathrm{Ar}-\mathrm{H}), 7.42(\mathrm{~m}, 1 \mathrm{H},=\mathrm{CH}-)$, $7.50(\mathrm{~m}, 1 \mathrm{H}, \mathrm{Ar}-\mathrm{H}), 7.68(\mathrm{~m}, 2 \mathrm{H}, \mathrm{Ar}-\mathrm{H}), 7.74(\mathrm{~m}, 1 \mathrm{H}$, $=\mathrm{CH}-), 7.78(\mathrm{~m}, 1 \mathrm{H}, \mathrm{Het}), 7.83(\mathrm{~d}, 1 \mathrm{H}$, Het $), 8.31(\mathrm{~d}, 1 \mathrm{H}$, Het).

2-[2-(4-nitrophenyl)ethenyl]quinolin-8-yl acetate (1c). The same procedure as for 1 a was used for 4-nitrobenzaldehyde. The solid residue was recrystallized from ethanol to give 1c yield $92 \%$. Mp 444-445 K. ${ }^{1} \mathrm{H}$ NMR $\left(400 \mathrm{~Hz}, \mathrm{DMSO}-\mathrm{d}_{6}\right), \delta$, ppm: $2.14\left(\mathrm{~s}, 3 \mathrm{H},-\mathrm{CH}_{3}\right), 7.43$ (d, 1H, Het), 7.54 (t, 1H, Het), $7.63(\mathrm{~d}, 1 \mathrm{H},=\mathrm{CH}-), 7.79$ (d, 1H, Het), $7.85(\mathrm{~m}, 1 \mathrm{H},=\mathrm{CH}-), 7.89(\mathrm{~m}, 1 \mathrm{H}$, Het), $7.95(\mathrm{~m}, 2 \mathrm{H}, \mathrm{Ar}-\mathrm{H}), 8.25(\mathrm{~m}, 2 \mathrm{H}, \mathrm{Ar}-\mathrm{H}), 8.36(\mathrm{~m}$, $1 \mathrm{H}, \mathrm{Het})$.

2-[2-(4-methoxyphenyl)ethenyl]quinolin-8-ol (2a). The solution of $1 \mathrm{a}(3.5 \mathrm{~g}, 11.07 \mathrm{mmol})$ in ethanol $(100 \mathrm{ml})$ and concentrated hydrochloric acid $(20 \mathrm{ml})$ was refluxed for $2 \mathrm{~h}$. The orange precipitate was filtered and washed thoroughly with water. It was subsequently dissolved in ethanol $(50 \mathrm{ml})$ and triethylamine $(17 \mathrm{ml})$ was added and stirred at room temperature for $1 \mathrm{~h}$. The ice-cool water was added and the precipitate was filtered, washed with water and dried to afford $\mathbf{2 a}$ as a bright yellow powder. It was purified by recrystallization from ethanol. Yellow crystals, yield $86 \%$. Mp $388 \mathrm{~K} .{ }^{1} \mathrm{H}$ NMR (400 Hz, DMSO-d ${ }_{6}$ ), $\delta$, ppm: 3.83 (s, $\left.3 \mathrm{H},-\mathrm{OCH}_{3}\right), 6.95$ (d, 2H, Ar-H), 7.62 (d, 2H, Ar-H); $7.26(\mathrm{~d}, 1 \mathrm{H},-\mathrm{CH}=)$, 8.00 (d, 1H, -CH=), 7.03 (d, 1H, Het), 7.22 (m, 1H, Het), 7.34 (t, 1H, Het), 7.67 (d, 1H, Het), 8.16 (d, 1H, Het). 9.11 $(\mathrm{s}, 1 \mathrm{H},-\mathrm{OH})$;

2-(2-phenylethenyl)quinolin-8-ol (2b). The same procedure as for 2a was used. Yellow crystals, yield $94 \%$. Mp 378 K. ${ }^{1} \mathrm{H}$ NMR $(400 \mathrm{~Hz}$, DMSO-d 6 ), $\delta$, ppm: 7.03 (d, 1H, Het), 7.27 (m, 1H, Het), 7.30-7.34 (m, 2H, Ar-H), $7.38(\mathrm{~m}, 1 \mathrm{H}, \mathrm{Ar}-\mathrm{H}), 7.41(\mathrm{~m}, 1 \mathrm{H},=\mathrm{CH}-), 7.42(\mathrm{~m}, 1 \mathrm{H}$, Het), 7.67-7.70 (m, 2H, Ar-H), 7.72 (m, 1H, Het), 8.07 (d, $1 \mathrm{H},=\mathrm{CH}-), 8.20(\mathrm{~d}, 1 \mathrm{H}, \mathrm{Het}), 9.17(\mathrm{~s}, 1 \mathrm{H},-\mathrm{OH})$.

2-[2-(4-nitrophenyl)ethenyl]quinolin-8-ol (2c). The same procedure as for $\mathbf{2 a}$ was used. Yellow-orange crystals, yield $87 \%$. Mp $473 \mathrm{~K} .{ }^{1} \mathrm{H} \mathrm{NMR}(400 \mathrm{~Hz}$, DMSO- $\left._{6}\right), \delta$, ppm: 7.05 (d, 1H, Het), 7.29 (d, 1H, Het), 7.36 (t, 1H, Het), 7.65 (d, 1H, =CH-), 7.73 (d, 1H, Het), $7.92(\mathrm{~d}, 2 \mathrm{H}, \operatorname{Ar}-\mathrm{H}), 8.21(\mathrm{~m}, 2 \mathrm{H}, \operatorname{Ar}-\mathrm{H}), 8.25(\mathrm{~m}$, $1 \mathrm{H},=\mathrm{CH}-), 8.28(\mathrm{~m}, 1 \mathrm{H}, \mathrm{Het}), 9.25(\mathrm{~s}, 1 \mathrm{H},-\mathrm{OH})$.

\subsection{Synthesis of 8-M ethacryloyloxy Styrylquinolines (M ASTQ)}

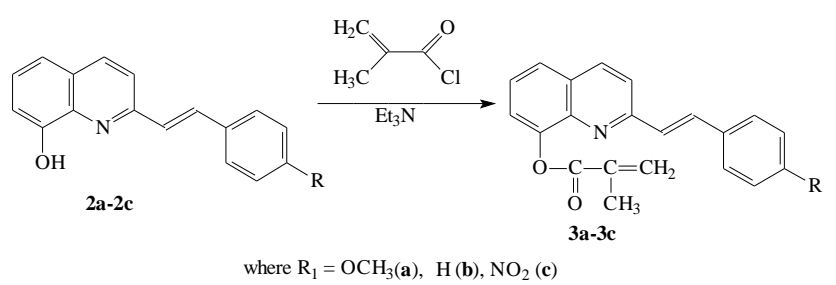

Scheme 2. Synthesis of 8-methacryloyloxy styrylquinolines

2-[2-(4-methoxyphenyl)ethenyl]quinolin-8-yl 2-methylpropyl-2-enoate (3a). A substance of $\mathbf{2 a}(2.6 \mathrm{~g}$, $9.3 \mathrm{mmol})$ was dissolved in THF $(10 \mathrm{ml})$ and triethylamine $(1.48 \mathrm{ml})$ was added. The solution was kept in an ice bath. The methacryloyl chloride (1 ml, $9.3 \mathrm{mmol}$ ) was added slowly to the reaction mixture. After the addition of methacryloyl chloride, solution was stirred for $4 \mathrm{~h}$ in an ice bath and then poured into ice-cool water. The light-yellow powder was collected by filtration, washed with water and dried. The product was recrystallized from toluene, yield $51 \%, \mathrm{Mp} 366 \mathrm{~K}$. ${ }^{1} \mathrm{H}$ NMR $(400 \mathrm{~Hz}$, DMSO-d 6 ), $\delta$, ppm: 2.21 (s, 3H, $\left.-\mathrm{CH}_{3}\right), 3.82\left(\mathrm{~s}, 3 \mathrm{H},-\mathrm{OCH}_{3}\right), 6.50\left(\mathrm{~s}, 1 \mathrm{H}, \mathrm{CH}_{2}=\right), 5.95(\mathrm{~s}$, $\left.1 \mathrm{H}, \mathrm{CH}_{2}=\right), 6.91$ (d, 2H, Ar-H), $7.54(\mathrm{~m}, 2 \mathrm{H}, \mathrm{Ar}-\mathrm{H}), 7.49$ $(\mathrm{m}, 1 \mathrm{H},-\mathrm{CH}=), 7.69(\mathrm{~m}, 1 \mathrm{H},-\mathrm{CH}=), 7.15$ (d, 1H, Het), 7.45 (m, 1H, Het), 7.66 (m, 1H, Het), 7.76 (d, 1H, Het), $8.25(\mathrm{~d}, 1 \mathrm{H}, \mathrm{Het})$. IR $\left(\mathrm{cm}^{-1}\right.$, the most characteristic bands): 1727, 1590, 1557, 1312, 976. 
2-(2-phenylethenyl)quinolin-8-yl 2-methylpropyl-2enoate $(3 \boldsymbol{b})$. The light yellow solid, yield $46 \%$. Mp $363 \mathrm{~K} .{ }^{1} \mathrm{H}$ NMR $\left(400 \mathrm{~Hz}\right.$, DMSO-d $\left.\mathrm{d}_{6}\right), \delta$, ppm: 2.30 (s, 3H, $\left.-\mathrm{CH}_{3}\right), 5.94\left(\mathrm{~s}, 1 \mathrm{H},=\mathrm{CH}_{2}\right), 6.50\left(\mathrm{~s}, 1 \mathrm{H},=\mathrm{CH}_{2}\right), 7.30(\mathrm{~d}$, 1H Het), 7.34 (d, 1H, Het), 7.39 (t, 1H, Het), 7.46 (d, 1H, $\left.=\mathrm{CH}_{2}-\right), 7.52(\mathrm{t}, 1 \mathrm{H}, \mathrm{Ar}-\mathrm{H}), 7.59(\mathrm{~d}, 2 \mathrm{H}, \mathrm{Ar}-\mathrm{H}), 7.71(\mathrm{~m}$, $\left.1 \mathrm{H},=\mathrm{CH}_{2}-\right), 7.75(\mathrm{~m}, 2 \mathrm{H}, \mathrm{Ar}-\mathrm{H}), 7.79(\mathrm{~m}, 1 \mathrm{H}, \mathrm{Het}), 8.30$ (d, 1H, Het). IR ( $\mathrm{cm}^{-1}$, the most characteristic bands): $1735,1599,1559,1318,972$.

2-[2-(4-nitrophenyl)ethenyl]quinolin-8-yl 2-methylpropyl-2-enoate $(\mathbf{3 c})$. The yellow solid, yield $70 \%$, Mp $432 \mathrm{~K}$. ${ }^{1} \mathrm{H}$ NMR $\left(400 \mathrm{~Hz}\right.$, DMSO-d $\left.{ }_{6}\right), \delta$, ppm: 2.30 (s, 3H, $\left.-\mathrm{CH}_{3}\right), 5.94\left(\mathrm{~s}, 1 \mathrm{H},=\mathrm{CH}_{2}\right), 6.47\left(\mathrm{~s}, 1 \mathrm{H},=\mathrm{CH}_{2}\right), 7.48(\mathrm{~d}$, $1 \mathrm{H} \mathrm{Het}), 7.55(\mathrm{~m}, 2 \mathrm{H}, 7-\mathrm{H}, \mathrm{Het}), 7.59\left(\mathrm{~m}, 1 \mathrm{H},=\mathrm{CH}_{2}-\right.$ ), 7.80-7.84 (m, 4H, Ar-H), 7.88 (m, 1H, Het), 8.22 (d, 1H, $\left.=\mathrm{CH}_{2}-\right), 8.39(\mathrm{~d}, 1 \mathrm{H}$, Het $)$. IR $\left(\mathrm{cm}^{-1}\right.$, the most characteristic bands): 1735, 1592, 1508, 1318, 978.

\subsection{Free Radical Polymerization}

The synthesis of homopolymers and copolymers based on methacrylic monomers (3a-3c, respectively) and methylmethacrylate (MMA) was conducted in $10 \%$ DMF solution with AIBN as radical initiator at $353 \mathrm{~K}$ (argon atmosphere). The mixture was degassed with repeated freeze and three cycles and then heated for 5-15 min. The polymerization was stopped by pouring the reaction mixture into methanol. The precipitation was repeated from DMF into methanol to get purified polymers. Synthetic route and chemical structures of the styrylquinoline containing copolymers are shown in Scheme 3.

\section{Results and Discussion}

\subsection{Characterization of Copolymers}

The ${ }^{1}$ H NMR spectra of poly(MASTQ), poly(MMA), and MASTQ-MMA copolymers. The peaks at $6.9-8.35 \mathrm{ppm}$ reveal the aromatic and heterocyclic protons of monomer units, and the signal at $3.8 \mathrm{ppm}$ is assigned to methyl adjacent to ester oxygen in MMA units. The other signals, 1.1-2.2 ppm, are due to the methyl and methylene protons of the main backbone in MASTQ and MMA units. The ${ }^{1} \mathrm{H}$ NMR technique is well established as a simple rapid, and accurate method for the determination of copolymer composition. The assignment of the resonance peaks in ${ }^{1} \mathrm{H}$ NMR spectrum allows for the accurate evaluation of the content of each kind of monomeric unit incorporated intensities into the copolymer chain. Thus, the mole fraction of MASTQ in the polymer chains were calculated from integrated intensities of aromatic protons of MASTQ and aliphatic protons MMA units. The following expression applies to copolymers.

\subsection{M onomer Reactivity Ratios}

The free radical copolymerization of various ratios MASTQ and MMA initiated by AIBN has been carried out at $353 \mathrm{~K}$. The copolymer compositions to determine monomer reactivity ratios were analyzed by ${ }^{1} \mathrm{H} N \mathrm{NR}$ spectra. Thus, the mole fractions of MASTQ and MMA in the copolymer were determined from the ratio of the integral intensities of aromatic and $-\mathrm{CH}=\mathrm{CH}-$ protons in MASTQ units, at $6.9-8.35 \mathrm{ppm}(11 \mathrm{H}-$ for $\mathbf{3 a}$ and $\mathbf{3 c}$, $12 \mathrm{H}-$ for $3 \mathbf{b}$ ), and methyl protons adjacent to oxygen at $3.8 \mathrm{ppm}$ for MMA units. For example, the mole fraction of $\mathbf{3 c}$ :MMA in copolymer have been calculated from the following equation:

$$
\begin{aligned}
3 c: M M A & =\frac{\text { Integral intensites at } 6.9-8.35 \mathrm{ppm}}{11}:- \\
& : \frac{\text { Integral intensites at } 3.8 \mathrm{ppm}}{3}
\end{aligned}
$$

For the copolymerization the behaviors of the system were evaluated through plots of the copolymer composition Fig. 1. The composition of copolymer obtained from the copolymerization technique showed azetropic composition at $F_{1}=0.4-0.5$. The monomer reactivity ratios, the content of the reaction mixture and the copolymer were calculated according to the FR and calculations methods.<smiles>[R]c1ccc(/C=C/c2ccc3cccc(OC(=O)C(C)(C)CC(C)(CCCCCCCC)C(=O)OC)c3n2)cc1</smiles>

Scheme 3. Synthesis of the styrylquinoline containing copolymers 
The F-R parameters of the free radical copolymerization of 3a and MMA

\begin{tabular}{|c|c|c|c|c|}
\hline Sample number & $f=M_{1} / M_{2}$ & $F=m_{1} / m_{2}$ & $f^{2} /(1-f)^{2} \cdot(1-F) / F$ & $f(1-2 F) /(1-f) F$ \\
\hline 1 & 0.25 & 0.33 & 0.2256 & 0.3434 \\
\hline 2 & 0.33 & 0.39 & 0.3794 & 0.2778 \\
\hline 3 & 0.50 & 0.49 & 1.0408 & 0.0408 \\
\hline 4 & 0.67 & 0.58 & 2.7287 & -0.5355 \\
\hline 5 & 0.75 & 0.64 & 5.0625 & -1.3125 \\
\hline
\end{tabular}

Notes: $M_{1}$ is mole fraction of $\mathbf{3 a}$ in reaction mixture; $M_{2}$ is mole fraction of MMA in reaction mixture; $m_{1}$ is mole fraction of 3a in copolymer; $m_{2}$ is mole fraction of MMA in copolymer.

Table 2

The F-R parameters of the free radical copolymerization of $3 \mathrm{~b}$ and MMA

\begin{tabular}{|c|c|c|c|c|}
\hline Sample number & $f=M_{1} / M_{2}$ & $F=m_{1} / m_{2}$ & $f^{2} /(1-f)^{2} \cdot(1-F) / F$ & $f(1-2 F) /(1-f) F$ \\
\hline 1 & 0.25 & 0.29 & 0.2720 & 0.4828 \\
\hline 2 & 0.33 & 0.35 & 0.4505 & 0.4222 \\
\hline 3 & 0.5 & 0.45 & 1.2222 & 0.2222 \\
\hline 4 & 0.67 & 0.54 & 3.2099 & -0.2876 \\
\hline 5 & 0.75 & 0.60 & 6.0000 & -1.0000 \\
\hline
\end{tabular}

Notes: $M_{1}$ is mole fraction of $\mathbf{3 b}$ in reaction mixture; $M_{2}$ is mole fraction of MMA in reaction mixture; $m_{1}$ is mole fraction of $\mathbf{3 b}$ in copolymer; $m_{2}$ is mole fraction of MMA in copolymer.

Table 3

The F-R parameters of the free radical copolymerization of $3 \mathrm{c}$ and MMA

\begin{tabular}{|c|c|c|c|c|}
\hline Sample number & $f=M_{1} / M_{2}$ & $F=m_{1} / m_{2}$ & $f^{2} /(1-f)^{2} \cdot(1-F) / F$ & $f(1-2 F) /(1-f) F$ \\
\hline 1 & 0.25 & 0.32 & 0.2361 & 0.3750 \\
\hline 2 & 0.33 & 0.38 & 0.3958 & 0.3111 \\
\hline 3 & 0.50 & 0.48 & 1.0833 & 0.0833 \\
\hline 4 & 0.67 & 0.57 & 2.7852 & -0.5064 \\
\hline
\end{tabular}

Notes: $M_{1}$ is mole fraction of $\mathbf{3 c}$ in reaction mixture; $M_{2}$ is mole fraction of MMA in reaction mixture; $m_{1}$ is mole fraction of $\mathbf{3 c}$ in copolymer; $m_{2}$ is mole fraction of MMA in copolymer.

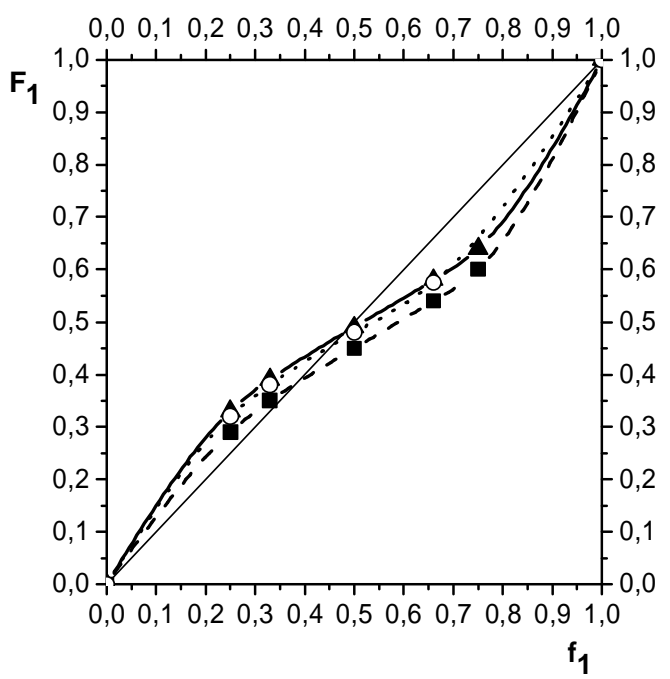

Fig. 1. Composition diagrams of the free radical copolymerization of $\mathbf{3 a}(\boldsymbol{\Delta}) ; \mathbf{3 b}(\boldsymbol{\nabla})$ and $\mathbf{3 c}(\bullet)$ with MMA

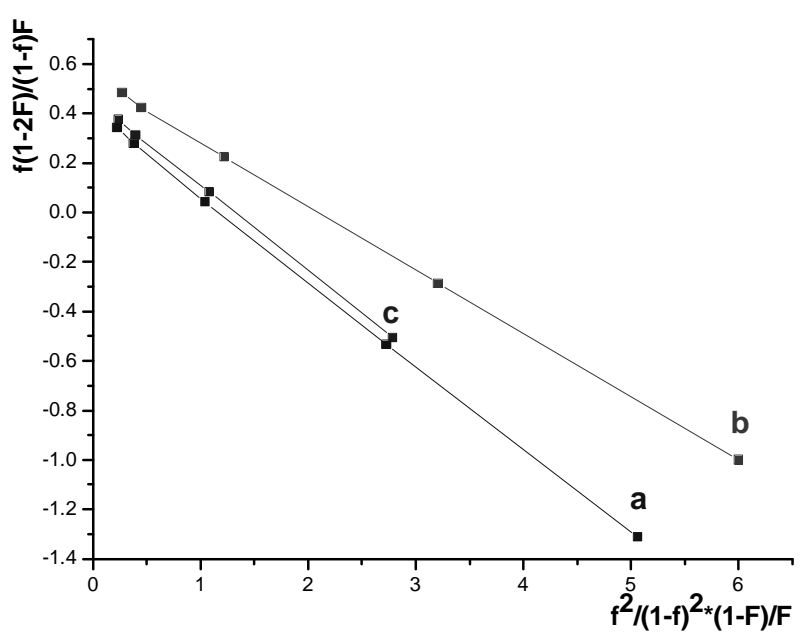

Fig. 2. Fineman-Ross plots for the free-radical copolymerization of 3a (a), 3b (b), 3c (c) with MMA 
Table 4

Monomer reactivity ratios and copolymerization parameters for MASTQ $\left(M_{1}\right)$ with MMA $\left(M_{2}\right)$

\begin{tabular}{|c|c|c|c|c|c|c|c|c|}
\hline \multirow{2}{*}{ MASTQ } & \multicolumn{2}{|c|}{ Fineman-Ross method } & \multicolumn{2}{|c|}{ Calculation method } & \multirow{2}{*}{$r_{1} \cdot r_{2}$} & \multirow{2}{*}{$1 / r_{2}$} & \multirow{2}{*}{$Q$} & \multirow{2}{*}{$e$} \\
\hline & $r_{1}$ & $r_{2}$ & $r_{1}$ & $r_{2}$ & & & & \\
\hline $\mathbf{3 b}$ & 0.26 & 0.55 & $0.255 \pm 0.004$ & $0.547 \pm 0.014$ & 0.14 & 1.82 & 2.37 & 1.80 \\
\hline $3 c$ & 0.33 & 0.44 & $0.327 \pm 0.004$ & $0.444 \pm 0.006$ & 0.15 & 2.27 & 2.91 & 1.79 \\
\hline $3 \mathbf{a}$ & 0.34 & 0.41 & $0.339 \pm 0.004$ & $0.411 \pm 0.011$ & 0.14 & 2.44 & 3.16 & 1.80 \\
\hline
\end{tabular}

The FR parameters were calculated for free radical copolymerization of MASTQ (3a, 3b, 3c) and MMA, and the results were summarized in Tables $1-3$. It is well known that monomer reactivity ratios can be indicative of relative reactivity of comonomers. In order to estimate the relative reactivity ratio of MASTQ and MMA in free radical copolymerization FR $[14,16]$ the next equation have been used:

$$
y=r_{2}-r_{1} \cdot x
$$

where $x=\left(f^{2} /(1-f)^{2} \cdot(1-F) / F\right.$ and $y=f(1-2 F) /(1-f) F$, respectively.

From the slope and intercept of the straight line, the monomer reactivity ratios of MASTQ and MMA were determined and found to be $r_{1}=0.34, r_{2}=0.41$ for $\mathbf{3 a}$ monomer; $r_{1}=0.26, r_{2}=0.55$ for $\mathbf{3 b}$ monomer; $r_{1}=0.33$, $r_{2}=0.44$ for $3 \mathbf{c}$ monomer (Fig. 2).

The copolymer composition equation has the form $y=r_{1} \cdot x+r_{2}$ : in the calculations method for the determination of $r_{1}$ and $r_{2}$.

$$
\frac{\left[M_{1}\right]}{\left[M_{2}\right]} \cdot\left(\frac{\left[m_{2}\right]}{\left[m_{1}\right]}-1\right)=-r_{1}\left(\frac{\left[M_{1}\right]}{\left[M_{2}\right]}\right)^{2} \cdot \frac{\left[m_{1}\right]}{\left[m_{2}\right]}+r_{2}
$$

where $y=\left[M_{1}\right] /\left[M_{2}\right] \cdot\left(\left[m_{2}\right] /\left[m_{1}\right]-1\right)$ and

$x=\left(\left[M_{1}\right] /\left[M_{2}\right]\right)^{2} \cdot\left[m_{2}\right] /\left[m_{1}\right]$

The copolymerization parameters of monomers $r_{1}$ and $r_{2}$ determined using the calculations method are presented in Table 4. However, the monomer reactivity ratios determined by calculation methods almost completely coincide with the ratios previously determined by the FR method.

It is well known that Price and Alfrey developed a simple scheme $(Q-e)$ to predict reactivity ratios of monomers participating in a free radical copolymerization [14]. From the $Q-e$ scheme the resonance stabilization parameter $Q$ and electronegativity parameter $e$ were calculated. The $Q-e$ scheme postulates that the reactivity ratio $r_{1}$ and $r_{2}$ can be expressed by Eqs. (4) and (5):

$$
\begin{aligned}
& r_{1}=\frac{Q_{1}}{Q_{2}} \exp \left[-e_{1}\left(e_{1}-e_{2}\right)\right] \\
& r_{2}=\frac{Q_{2}}{Q_{1}} \exp \left[-e_{2}\left(e_{2}-e_{1}\right)\right]
\end{aligned}
$$

The $Q-e$ values of MMA have been found in the literature [17] to be the following $Q=0.74, e=0.4$. The $Q-e$ values of $3 \mathbf{a}, \mathbf{3 b}, \mathbf{3} \mathbf{c}$ have been found to be $Q=3.16$, $e=1.8$ for 3a; $Q=2.37, e=1.8$ for $\mathbf{3 b}$; $Q=2.91, e=1.79$ for 3c. The monomer reactivity ratios and copolymerization parameters are presented in Table 4.

The values of parameter $r_{1}$ illustrate similar values obtained with using two different methods. These values can be explained by insufficient influence of substitute effect.

The values of reverse constants $1 / r_{2}$ were calculated, all three new monomers can join the radical of MMA actively, moreover, the most active is monomer with methoxy group. The similar and low values of $r_{1} \cdot r_{2}$ illustrate the common tendency of MASTQ to interchange with links of MMA. The values of $Q$ parameters have correlated with the values of $1 / r_{2}$, and the values of the polar factor e have been almost identical for all monomers.

\section{Conclusions}

Copolymers of MASTQ with MMA were prepared by free radical polymerization. The monomer reactivity ratios for MASTQ-MMA system were calculated from the feed composition and copolymer composition determined by ${ }^{1} \mathrm{H}$ NMR spectroscopy. The monomer reactivity ratios of MASTQ and MMA were computed using Fineman-Ross (F-R) and calculation methods (in the brackets) and were found to be $r_{1}=0.34$ (0.339 \pm 0.004$), r_{2}=0.41(0.411 \pm 0.011), Q=3.16, e=1.8$ for monomer with $\mathrm{CH}_{3} \mathrm{O}-$ group; $r_{1}=0.26$ (0.255 \pm 0.004$), r_{2}=0.55(0.547 \pm 0.014), Q=2.37, e=1.8$ for 2-styrylquinolin-8-ol methacrylate; $r_{1}=0.33$ $(0.327 \pm 0.004), \quad r_{2}=0.44 \quad(0.444 \pm 0.006), \quad Q=2.91$, $e=1.79$ for monomer with $\mathrm{NO}_{2}-$ group.

\section{References}

[1] Dalton L.: Nonlinear Optical Polymeric Materials: From Chromophore Design to Commercial Applications [in:] Lee K.-S. (Ed.), Polymers for Photonics Applications I, Springer/Heidelberg Publisher, Berlin 2002, 1-86.

[2] Nahata A.: Opt. Soc. Am. B., 1993, 10, 1553.

https://doi.org/10.1364/JOSAB.10.001553

[3] Derkowska-Zielinska B. et al.: Proceedings of SPIE - The International Society for Optical Engineering, 2015, 9652, 965216. [4] Czaplicki R. et al.: Opt. Express., 2007, 15, 15268.

https://doi.org/10.1364/OE.15.015268 
[5] Derkowska-Zielinska B. et al.: Opt. Mat., 2015, 49, 325. https://doi.org/10.1016/j.optmat.2015.10.001

[6] Ayaz N. et al.: ISRN Polym. Sci., 2012, 2012, 13. https://doi.org/10.5402/2012/352759

[7] Tang C., VanSlyke S.: Appl. Phys. Lett., 1987, 51, 913. https://doi.org/10.1063/1.98799

[8] Budyka M., Potashova N.: Nanotechnol. Russia, 2012, 7, 280. https://doi.org/10.1134/S1995078012030032

[9] Budyka M., Potashova N.: High Energ. Chem., 2010, 44, 404. https://doi.org/10.1134/S0018143910050097

[10] Mekouar K., Mouscadet J.-F.: J. Med. Chem., 1998, 41, 2846. https://doi.org/10.1021/jm980043e

[11] Podeszwa B., Niedbala H., Polanski J.: Bioorg. Med. Chem. Lett., 2007, 17, 6138. https://doi.org/10.1016/j.bmcl.2007.09.040 [12] Mao F., Yan J., Li J.: Org. Biomol. Chem., 2014, 12, 5936. https://doi.org/10.1039/C4OB00998C

[13] Mrozek-Wilczkiewicz A., Kalinowski D., Musiol R.: Bioorg. Med. Chem., 2010, 18, 2664.

https://doi.org/10.1016/j.bmc.2010.02.025

[14] Alfrey T., Price C.: J. Polym. Sci., 1947, 2, 101.

[15] Gordon A., Ford R.: The Chemist's Companion: A Handbook of Practical Data, Techniques, and References, Wiley, New York 1972.

[16] Fineman M., Ross S.: J. Polym. Sci., 1950, 5, 259.

https://doi.org/10.1002/pol.1950.120050210
[17] Brandrup J., Immergut E., Grulke E.: Polymer Handbook. Wiley \& sons, New York 1999.

Received: January 30, 2017 / Revised: February 13, 2017 / Accepted: May 23, 2017

\section{РЕАКЦІЙНА ТА ПОЛІМЕРИЗАЦИЙНА ЗДАТНІСТЬ СТИРИЛХІНОЛІНВМІСНИХ МЕТАКРИЛОВИХ МОНОМЕРІВ}

Анотація. Синтезовано нові стирилхінолінвмісні метакрилові мономери та їх кополімери з метилметакрилатом (ММА). Полімеризацію проводили в ДМФ, як ініціатор використовували АІБН. Продукти полімеризації охарактеризовано за допомогою ${ }^{I}$ Н ЯМР. Реакційну здатність нових метакрилових мономерів на основі стирилхіноліну для гомогенної вільно-радикальної кополімеризаиії з ММА визначено за даними ${ }^{1}$ Н ЯМР спектроскопї̈ та проведено ї̈ оцінювання за методом Файнмана-Росса і розрахунковим методом.

Ключові слова: 8-метакрилокси стирилхінолін, метод Файнмана-Росса, реакційна здатність мономеру, вільнорадикальна полімеризачія. 